\title{
Motivation and barriers to participation in virtual knowledge-sharing communities of practice
}

\author{
Atieh Javadpour $^{\mathrm{a}^{*}}$ and Somayeh Samiei ${ }^{\mathrm{b}}$
}

${ }^{a} M . S$ in Knowledge and Information Science ${ }^{b}$ M.S in Knowledge and Information Science

\begin{tabular}{|c|c|}
\hline CHRON I C L E & A B S T RACT \\
\hline $\begin{array}{l}\text { Article history: } \\
\text { Received: October } 1,2016 \\
\text { Received in revised format: No- } \\
\text { vember } 16,2016 \\
\text { Accepted: November } 28,2016 \\
\text { Available online: } \\
\text { November } 29,2016\end{array}$ & $\begin{array}{l}\text { The present study has been conducted in order to investigate the documentation of the organi- } \\
\text { zational knowledge condition from the managers' perspective of libraries, museums, and Doc- } \\
\text { uments Center of Astan Quds Razavi based on Dalkir model [Dalkir, K. (2005). Knowledge } \\
\text { Management in Theory and Practice. Elsevier. Butterworth-Heinemann.]. The survey popula- } \\
\text { tion consisted of all managers of Astan Quds libraries. The relevant information was gathered } \\
\text { using a researcher-created the questionnaire based on Dalkir model of knowledge management }\end{array}$ \\
\hline $\begin{array}{l}\text { Keywords: } \\
\text { Documentation } \\
\text { Organizational Knowledge }\end{array}$ & $\begin{array}{l}\text { cycle. Findings revealed that in all six dimensions of knowledge documentation, obtained means } \\
\text { were less than intermediate level (3) and documentation status in all studied dimensions of } \\
\text { Dalkir's model was not suitable. }\end{array}$ \\
\hline
\end{tabular}

Dalkir' model

Libraries, museums and Docu-

ment center of Astan Quds Razavi

\section{Introduction}

In the information era, knowledge is the vital and critical source of organizations as it paves the way for achieving sustainable competitive advantage. Instead of material capitals, the power of individuals' mind governs over them. During the natural actions of organizations, organizational knowledge is raised which need to be taken care of appropriately and the generated knowledge should be handed the staff for retrieval. On the other hand, organizational knowledge is being lost because organizations are continuously becoming smaller, depending on outside forces and going off from using knowledgeoriented professionals.

The median time that a highly skilled and experienced employee spends in an organization has significantly diminished. This can be ascribed to factors such as small size of governing bodies, pension and displacement and possibly it is deliberately employed (Dalkir, 2005). In most organizations, objective or identified and coded knowledge, including reports, user guide, trends and e- mail messages which are often digitally saved in a database, Wiki, Blog or Intranet, only represent a small part of all what is available (Wiig, 1995). Besides, many organizations have designed and carried out plans for recording

* Corresponding author.

E-mail address: aj.lib13@gmail.com (A. Javadpour) 
tacit and implicit knowledge and replacing employees. This process is usually accomplished through transferring technical knowledge of the employee leaving the organization to the individual who is appointed for the replacement with emphasis on the collective intellect design of current and past employees (Davenport \& Prosuk, 1998). One of the problems and challenges of organizations is that generated knowledge capitals are not documented by their employees. This generated knowledge merely remains in their minds without any documentation so there is no possibility of reusing it. On the other hand, the exit of organization elites' knowledge and experiences is due to the retirement and loss of experts, who have been active in the organization for years. Therefore, knowledge acquisition from organizational elites not only avoids a repeat of experience in the organization, but also it helps to the development of new knowledge. In this regard, knowledge acquisition from the elites constitutes an important and critical part of all activities in knowledge management (Afrazeh, 2005). Knowledge documentation is the process that contributes to knowledge acquisition from elites. It is the pivotal step in knowledge management. This means that if the organizational knowledge and experiences are not documented, the other steps in knowledge management will fail. Documentation discovers, organizes and uniform knowledge in the body of the organization; such that documented and coded knowledge are converted to a part of the existing knowledge database of the organization (Dalkir \& Liebowitz, 2011). Organizations engaged in documentation of organizational knowledge guarantee continuity of the best practices and experiences and prevent recurrence of the past mistakes as well (Davenport \& Prosuk, 2000).

The main issue of the present research, namely, is to investigate the barriers to the documentation of organizational knowledge from the managers' perspective based on Dalkir model carried out in the organizations of libraries, museums and documents center of Astan Quds Razavi as one of the largest service organizations in the field of book and library. Thus, the purpose of this study is to identify the status of knowledge documentation in this organization through six dimensions. Hence, the main question of the present study is:

Q1: What is the status of the documentation of organizational knowledge from the managers' perspective based on the integrated knowledge life cycle of Dalkir's (2005) model ?

In this paper, six main dimensions of Dalkir's model are examined, namely; knowledge acquisition or creation; knowledge assessment; knowledge sharing and distribution; conceptualization and coding knowledge (contextualizing); understanding and application of knowledge and knowledge updating . Before addressing the findings of the study, it is necessary to briefly explain Dolkir's (2005) integrated model of knowledge management cycle.

\section{Dalkir's (2005) integrated model of knowledge management cycle}

Any action and planning in the field of knowledge documentation require a strong theoretical foundation and conceptual framework, Otherwise, it might not lead to coordinated practices and activities and consequently the desired results would not be achieved (Dalkir \& Liebowitz, 2011). Most models of knowledge management ranging from theoretical to life cycle models which are similar to each other in terms of content, but include expressions and stages with different combinations emphasize on the use and application of knowledge and other steps are considered as an introduction for the creation of necessary conditions to use it (Afrazeh, 2005). These models are neither comprehensive nor include a detailed explanations about each step (Dalkir \& Liebowitz, 2011). The process of registration and coding knowledge is not included in these models either (Anand \& Sing, 2011).

Based on previous studies and approaches, Dalkir (2005) suggested a combined approach for knowledge management, which involves three main stages, namely, 1) the capture or creation of knowledge, 2) sharing and distribution of knowledge 3) acquisition and application of knowledge. At 
the time of transition from knowledge acquisition or creation stage to knowledge sharing and distribution stage, and then in order to understand and apply this knowledge, content of knowledge assessment is transformed into text. Then in order to update the content of knowledge this stage feedbacks to the first stage.

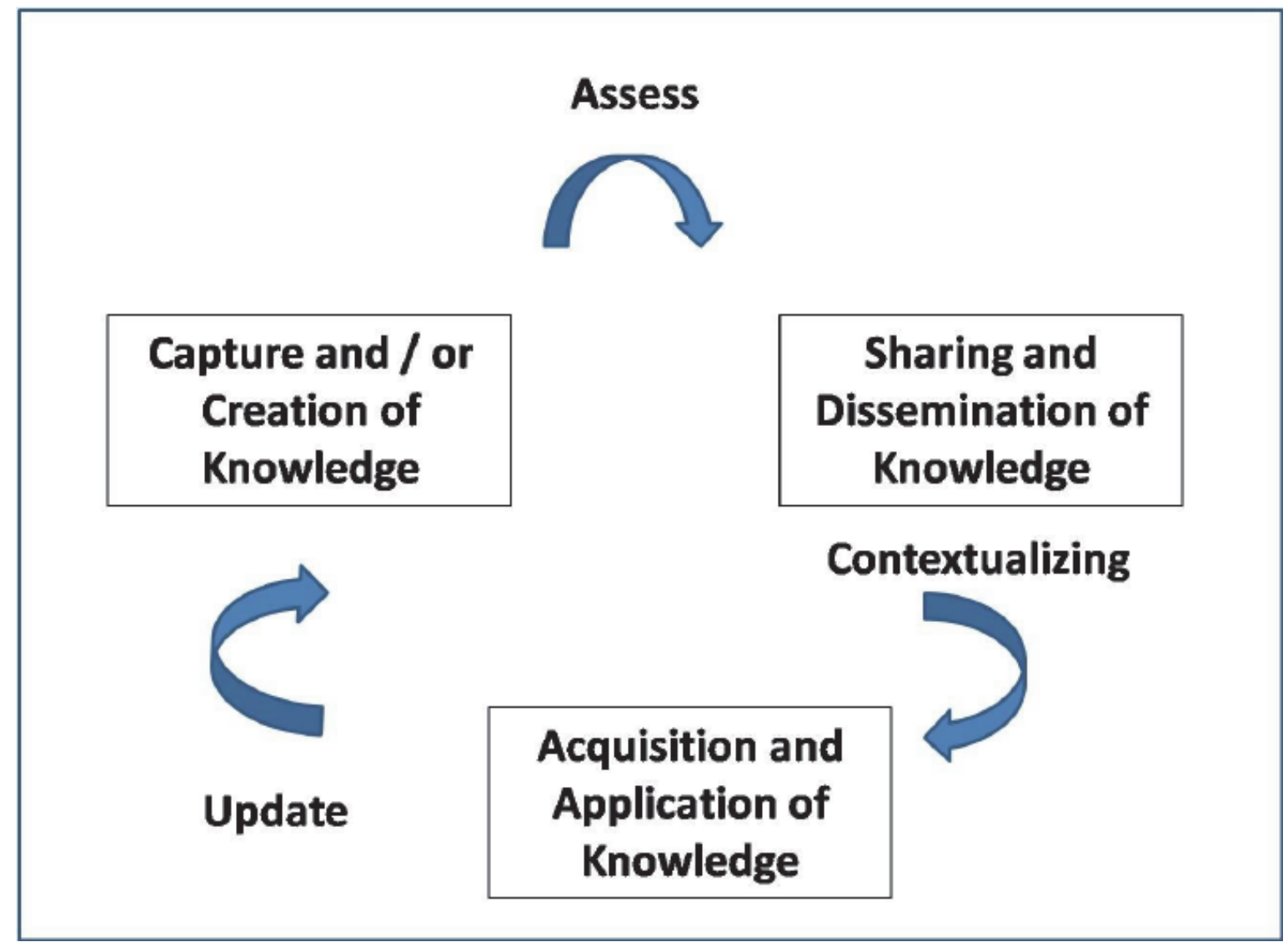

Fig. 1. Knowledge management cycle (Dalkir, 2005)

\section{Methodology}

The present study is an applied, descriptive-survey study. The population consisted of 40 senior managers of libraries, museums and Documents Center of Astan Quds Razavi, Iran. Since the population was limited, so sampling was not carried out and a questionnaire was distributed among all of them. Instrument for gathering required data included researcher-made questionnaire was based on Dolkir's knowledge management cycle model. Mentioned questionnaire had 94 closed items. The questionnaire was distributed among all members of the population. Only 32 subjects completed it and obtained information from completed questionnaires were analyzed.

It is worth mentioning that validity of the questionnaire was confirmed by experts in the field and its reliability was also computed by Cronbach alpha. In general overall $\alpha(\alpha=0.974)$ was obtained from this questionnaire. It indicates the internal consistency of the questionnaire items and accordingly its reliability. The answers were ranked according to five-point Likert scale. In order to analyze data in two levels of inferential and descriptive, SPSS program (version 18) was used. 


\section{Findings}

After collecting data, one sample Student t-test was used to analyze the status of each of six dimensions of knowledge documentation. Relevant findings were presented in Table 1 below.

\section{Table 1}

The results of t-test for the investigation of organizational knowledge documentation status based on Dolkir's (2005) integrated model of the knowledge life cycle

\begin{tabular}{|c|c|c|c|c|c|c|c|}
\hline \multirow[b]{2}{*}{ Valid / Dimension } & \multirow[b]{2}{*}{ Frequency } & \multirow[b]{2}{*}{ Mean } & \multicolumn{5}{|c|}{ Means comparison test } \\
\hline & & & $\mathrm{T}$ & df & $\begin{array}{l}\text { Sig }(2- \\
\text { tailed })\end{array}$ & Lower & Upper \\
\hline Capture or creation of knowledge & 32 & 2.09 & -10.992 & 31 & 0 & -1.07 & -0.735 \\
\hline Knowledge assessment & 32 & 1.95 & -14.75 & 31 & 0 & -1.18 & -0.897 \\
\hline Knowledge sharing and distribution & 32 & 2.06 & -10.08 & 31 & 0 & -1.12 & -0.747 \\
\hline $\begin{array}{l}\text { Conceptualization and codifying of } \\
\text { knowledge (contextualizing) }\end{array}$ & 32 & 1.83 & -12.48 & 31 & 0 & -1.35 & -0.977 \\
\hline Acquisition and application of knowledge & 32 & 1.94 & -10.85 & 31 & 0 & -1.252 & -0.856 \\
\hline Updating content knowledge & 32 & 2.07 & -7.12 & 31 & 0 & -1.18 & -0.657 \\
\hline
\end{tabular}

As illustrated by findings in Table 1 and obtained mean for each of six dimensions of organizational knowledge documentation, it can be concluded that in all dimensions obtained means were less than intermediate level (3). Since the significance level (p-value) for all studied dimensions was also less than 0.05 , therefore it can be concluded that the status of various dimensions of organizational knowledge documentation of this organization was not in average level. On the other hand, the obtained means are less than average. So there should be some basic planning to promote this status.

\section{Conclusion}

The findings of the present study have revealed that based on obtaining means for all six dimensions of organizational knowledge documentation, it can be concluded that in all dimensions obtained means were less than intermediate level (3) and also the status of different dimensions of organizational knowledge documentation was not average in this organization (Table 1). Findings of a study by Ahmadi, (2008) indicated that from elites and expert's perspective, required behavioral and cultural variables for documentation of managers' experiences and strategies for recording experience were less than average in Iran. Along with the findings of the present study, Jamshidi Broujeni (2013) found that status of libraries in terms of documentation was relatively undesirable but their managers were highly aware of the importance of documentation. Similarly, the results of a study conducted by Khosravi et al. (2012) on the evaluation of the status of knowledge maintenance in the international energy studies institute indicated an average level of this organization.

The reason for such finding in the present study might lie in the lack of compiled strategies for the documentation of organizational knowledge, lack of motivation among managers, tact management methods, and managers' unawareness of how and what documentation is as well as its nature and essence; Jamshidi Brojeni (2013) also considered the existence of five fundamental factors of structural, cultural, legal, technological and behavioral with respect to their priority as necessary elements in documentation. In the same vein, according to Nazim and Mukherjee (2013) individuals' lack of information in terms of concepts and advantages of knowledge management, knowledge sharing culture, and formal structure and required technological infrastructures for knowledge management are among 
the main reasons for not taking organizational knowledge documentation into account. Maponya (2005) stated the lack of systematic strategy and method in libraries for the publication of personnel's individual knowledge as the main factor and considers this influential issue as the cause of losing their knowledge and experiences.

According to the findings of the present study and other similar studies, it can be inferred that libraries, museums, and documents center of Astan Quods Razavi organizations need to redefine most of their processes in their own organizational knowledge documentation because based on these findings, all of these organizations have no defined and determined plan for six components of knowledge documentation and the importance of employees' knowledge and experience and the role of intellect capitals in transformation and innovation has been overlooked. Therefore, a change in management system and knowledge documentation in this organization and employees' knowledge promotion is the point which should be taken into account. In order to enhance employees' motivation and knowledge, organizational knowledge documentation in the organization in, holding training courses as well as providing required encouragements can be effective.

\section{Acknowledgement}

The authors would like to thank the anonymous referees for constructive comments on earlier version of this paper.

\section{References}

Afrazeh, A. (2005). Knowledge management, concepts, models, measurements and implementation. Tehran. Senate Amirkabir Publications.

Ahmadi, S. A. A., Elahi, S., \& Salehi, A. (2008). Investigation and formulation of behavioral, cultural factors and strategies for recording managers' trade. Daneshvar Rafter, 15(29), 17-28. (In Persian).

Anand, A., \& Singh, M.D. (2011). Understanding knowledge management: a literature review. International Journal of Engineering and Science and Technology,3(2), 926-938.

Alavi, M., \& Leidner, D. E. (2001). Review: Knowledge management and knowledge management systems: Conceptual foundations and research issues. MIS quarterly, 25(1), 107-136.

Dalkir, K. (2005). Knowledge Management in Theory and Practice. Elsevier. Butterworth-Heinemann.

Dalkir, K., \& Liebowitz, J. (2011). Knowledge Management in Theory and Practice. MIT press.

Davenport, T. H., \& Prusak, L. (1998). Working knowledge: How organizations manage what they know. Harvard Business Press.

Jamshidi Broujeni, G. (2013). Identification and analysis of Iran university library managers' views on knowledge and experiences documentation for providing strategies for documentation in the libraries. MA thesis. Psychology and training science college, Ahvaz Shahid Chamran University.

Khosravi, F., Momeni, E., \& Gholami, R. (2012). An assessment study of knowledge in institution for international energy studies. Information Systems \& Services, 1(3), 39-52.

Maponya, P. M. (2005). Knowledge management practices in academic libraries: a case study of the University of Natal, Pietermaritzburg Libraries.

Nazim, M., \& Mukherjee, B. (2013). Librarians' perceptions of knowledge management in developing countries: A case with Indian academic libraries. The International Information \& Library Review, 45(1-2), 63-76.

Wiig, K. M. (1995). Knowledge Management Methods-Practical Approaches to Managing Knowledge; Arlington TX. 
(C) 2017 by the authors; licensee Growing Science, Canada. This is an open access article distributed under the terms and conditions of the Creative Commons Attribution (CC-BY) license (http://creativecommons.org/licenses/by/4.0/). 